\section{On copyright}

\section{Copyright in the networked world: moral rights}

\author{
Michael Seadle
}

\section{The author}

Michael Seadle is Editor of Library Hi Tech. He is also Digital Services and Copyright Librarian at Michigan State University. He is not a lawyer, and nothing in this column should be considered legal advice.

E-mail: seadle@mail.lib.msu.edu

\section{Keywords}

Copyright, Ethics

\section{Abstract}

In copyright law, the principle of moral rights is that some part of the creator's personality has gone into each original work, and that that element of personality cannot be sold or transferred. Moral rights are not about money, which is readily divisible, but about concepts like reputation and integrity, which are not. This column offers three examples of international collaborations where moral rights expectations could clash. At present the best remedy for moral rights disputes in the neworked environment is for all parties to understand the potential for diverging expectations.

\section{Electronic access}

The research register for this journal is available at http://www.emeraldinsight.com/researchregisters

The current issue and full text archive of this journal is available at http://www.emeraldinsight.com/0737-8831.htm

Library Hi Tech

Volume $20 \cdot$ Number $1 \cdot 2002 \cdot$ pp. 124-127

(C) MCB UP Limited · ISSN 0737-8831

\section{Introduction}

The term "moral rights" is a translation of the French term "droit moral", and refers not to "morals" as advocated by the religious right, but rather to the ability of authors to control the eventual fate of their works. An author is said to have the "moral right" to control her work. The concept of moral rights thus relies on the connection between an author and her creation. Moral rights protect the personal and reputational, rather than purely monetary, value of a work to its creator (Rosenblatt, 1998).

Language matters, especially in a networked world with multinational and multi-cultural projects. Literal translation of the French term has made "moral rights" seem broader and vaguer than they are. The equivalent German phrase (Urheberpersönlichkeitsrechte) may sound formidable to an ear accustomed to English, but a direct translation actually conveys something closer to the legal meaning embodied in the Berne Convention: rights of (a particular) personality. The principle is that some part of the creator's personality has gone into each original work, and that that element of personality cannot be sold or transferred any more than a human being can be today.

These moral rights (rights of personality) in general include attribution and integrity. Attribution means both that authors have their names on the works that they created, and that their names do not appear on works that are not theirs. Integrity means that authors can protect works they created from damage or defacement that affects their reputation. The precise legal definitions varies from country to country. An example of infringement on the moral right of attribution is when a book appears without the author's name. Wellknown authors may also face situations where their names appear on works to enhance sales, even though they had little or nothing to do with the work and do not want to support it. An example of a violation of the moral right of integrity could be a translation so bad that the author disavows it. These are not the only possible moral rights. The right to withdraw a work from public availability also exists in some countries.

Moral rights are not about money, which is readily divisible, but about concepts like reputation and integrity, which are not. The 
anger involved in moral rights

misunderstandings stems from a sense of personal mistreatment. Moral rights disputes can be litigated in courts as readily as cashbased copyright quarrels, but the case law for moral rights is relatively scanty, perhaps because the damage is less readily resolved than with purely financial settlements. This lack of litigation could lead people to think either that moral rights do not matter, or that they are so obvious that no decent person would violate them. Neither is entirely true. Despite the best efforts of the Berne Convention, the moral rights legislation varies broadly among members, especially between the USA and western Europe. This means that the assumptions on which people base their behaviors and expectations also lack homogeneity. At a time when many organizations are trying to promote international projects, different moral rights assumptions can pose a danger to cross-cultural cooperation.

This column offers three examples of international collaborations where moral rights expectations could clash. These examples are (partially) fictional, and meant to illustrate differences in the law and culture, not to provide legal commentary. The person raising the issue in each case comes from Germany, where the moral rights tradition is well established and the legislation quite explicit. While US citizens can and occasionally do assert their moral rights, moral rights play a small and very new role in the Anglo-US copyright tradition.

\section{Attribution example}

A German works with a Canadian and a US citizen on an informational article for an online German-based European publication. Since the work is aimed at a broad international audience (including Americans), the language is English, and the US author takes the lead in crafting the final product, which consists of specific sections from each person. The Canadian writes a small and essentially factual portion (roughly onesixth). The German writes twice as much (roughly one-third), and the US author writes about half of the total. When the final draft is ready, the US author assumes sole authorship. He did most of the work and reasons that the others were mainly supplying information, for which he thanks them heartily in the text. The Canadian agrees. No money is involved. His work was minimal. Giving up any claim to authorship seems like a small way of thanking the person without whom the article would never have appeared. The German, however, claims a violation of his moral right of attribution.

Under German law, the German author has a reasonable complaint. He sent a section of text, which was his expression of the information he was providing. The information had not been published elsewhere and essentially only made sense within the context of the whole article (an important point). German law allows for both horizontal and vertical co-authorship. (Schulze, 1988, p. 64) That is, a co-author can contribute to the whole or to particular parts. German law also protects the moral right of a co-author to having his name on the work. It does not matter whether one of the other authors did more of the work or wrote a larger section of the article. The right of attribution is clear and inalienable - it cannot be transferred to someone else, either by written assignment as economic rights can be, or by implicit consent. The author need not assert the right if he decides that future collaboration would make it better not to. But if he asserts it, the right is plain.

For the US author, this is not really a copyright issue at all. US law has no moral rights statute for moral rights in text-based materials. The only US moral rights legislation is the Visual Artists Rights Bill, which can be found in Title 17 of the United States Code, section 106A (17 USC 106A), and which limits moral rights to "the author of a work of visual art" (17 USC 106a). When the US joined Berne, the Congress claimed that the common law of misrepresentations and unfair competition, and the Lanham Act (15 USC 1125 (a)(1)(A)) contained "rights equivalent to moral rights of authors" (Standler, 1998) As a practical matter, neither seems to apply to this kind of situation, which is not deliberate misrepresentation but inadvertent misunderstanding. US copyright law is silent about attribution requirements for text-based 
materials. Its focus is on the economic issues, and in this case, there are none.

The Canadian law more resembles the European, but is distinctly laconic:

14.1 (1) The author of a work has, subject to section 28.2 , the right to the integrity of the work and, in connection with an act mentioned in section 3, the right, where reasonable in the circumstances, to be associated with the work as its author by name or under a pseudonym and the right to remain anonymous (Canada, Department of Justice, 2001).

Although the right of attribution exists, it seems strongly hedged by the qualifying phrase "reasonable in the circumstances". It is not hard to understand that the Canadian author might well find this to be case where it is not reasonable to insist.

\section{Integrity example}

A German artist cooperates with a digital library project run from a US university. The artist accepts a six-month salary (with benefits) in order to create five digital paintings on special large, flat-screen monitors. She uses a very deliberate choice of colors and shades of colors to create a particular feeling - the specialty on which she feels her reputation rests. The digital library project mounts the digital paintings in a physical gallery but the monitors that it uses have different color balances than the original. When the artist sees the works, she is horrified that the colors are wrong, and claims that these damage the integrity of her work. She asserts her moral right to have them withdrawn.

In this case, US moral rights statutes could apply under two clauses:

Subject to section 107 and independent of the exclusive rights provided in section 106, the author of a work of visual art - ... (2) shall have the right to prevent the use of his or her name as the author of the work of visual art in the event of a distortion, mutilation, or other modification of the work which would be prejudicial to his or her honor or reputation; and (3) subject to the limitations set forth in section $113(\mathrm{~d})$, shall have the right - (A) to prevent any intentional distortion, mutilation, or other modification of that work which would be prejudicial to his or her honor or reputation, and any intentional distortion, mutilation, or modification of that work is a violation of that right ... 17 USC 106A).
Even though this is a digital work, it seems reasonable to assume that it is a work of visual art under US law. The more difficult question is whether the color problem represents a distortion, mutilation, or other modification that is prejudicial to honor and reputation. It is important to realize that this is not a question about whether the color settings on computer monitors harms economic worth, but whether it harms reputation. In the event of an actual lawsuit, a panel of peers might advise the court, and could well favor their fellow artist. The legal issue might, however, be whether the damage were "result of the passage of time or the inherent nature of the materials" (17 USC $106 \mathrm{~A}(\mathrm{c}))$ In that case, the situation would not represent a distortion, mutilation, or modification, and moral rights would not be affected.

Thus far the artist could win. But a more uniquely American problem is whether the digital paintings represent works-for-hire. Work-for-hire is a well-established part of Anglo-US copyright law, and is allowed under the Berne Convention. In the US an artist does not own the moral rights to a work created in a work-for-hire arrangement, something which would be impossible under German law, where copyrights must belong to "a natural person, a human, not a corporation, a society, a state or other form of legal being" (Schulze, 1998, p. 61)

In US case law, the so-called "Reid Factors" have been used to determine work-for-hire status. These include:

... the hiring party's right to control the manner and means by which the work is produced; the skill required to accomplish the work; the source, or owner, of the tools and instrumentalities used to produce the work; the location of the work; the duration of the relationship between parties; the right of the hiring party of assign additional projects to the hired party; the extent of discretion the hired party has over when and how long she works; the method of payment, the hired party's role in hiring and paying assistants; whether the work is part of regular business of the hiring party; whether the hiring party is in business; the provision of employee benefits; and the tax treatment of the hired party (Fielkow, 1997, p. 6).

While the Reid factors have been applied irregularly, the weight given to payment methods, and especially employee benefits and 
tax treatment suggests an expectation in the USA that the work would belong to the institution that paid the artist's salary. (Feilkow, 1997, p. 13). The German artist might well discover that she had no moral rights to claim simply because she accepted a salary arrangement rather than a benefit-free check, even though the salary and benefits had nothing to do with that measure of her own personality that went into creating the art.

\section{Inheritance example}

A young German sculptor works at a US university, where his main job is create a set of statues for the outside of new library. The library director likes the statues so well that, with the artist's permission, they become an integral part of the logo that the library uses on its Web site. Year after year at homecoming the students paint the statues purple (the school color). The university always clean the statues off at the sculptor's insistence, but after he unexpectedly dies in a traffic accident, they decide to leave the color, and even change the color on the library logo. The sculptor's German parents assert his moral rights and insist that the original color be restored, both to the statue and to the logo on the Web site.

Under German law, the moral rights remain for 70 years after death, the same duration as for economic protection. (Schultze, 1998, p. 70). Under US law, they only "endure for a term consisting of the life of the author" (17 USC 106A (d)). In other words, the artist's moral rights died with him under US law. The potentially complex questions about whether the moral rights also apply to the derivative image of the statue in the logo are irrelevant.

\section{Conclusion}

Moral rights represent one of the last areas where US copyright law fundamentally diverges from that of its major trading partners and from its major digital and networking collaborators.
To some extent the divergence represents a philosophical clash between the Anglo-US tradition, with its strict economic emphasis, and the natural rights basis of continental European law. But the UK has managed to incorporate substantially more moral rights legislation into its copyright tradition than the USA, despite some interesting exceptions, such as "where material is used in newspapers or magazines" (UK Patent Office, nd). Canada also has further reaching moral rights for authors than the USA.

The examples offered in this article highlight only some of the legal and cultural differences that are possible. Misunderstandings will occur. At present the best remedy for moral rights disputes in the networked environment is for all parties to understand the potential for diverging expectations.

\section{References}

17 USC 106A, United States Code, Title 17, Chapter 1, section 106A, available (December, 2001) at: www4.law.cornell.edu/uscode/17/106A.html

Berne Convention for the Protection of Literary and Artistic Works (1971), Paris Text, available (December, 2001) at: www.law.cornell.edu/treaties/berne/6bis.html

Canada, Department of Justice (2001), Copyright Act, Chapter C42 (April 30), available (December 2001) at: lois.justice.gc.ca/en/C-42/33333.html

Fielkow, C.C. (1997), "Clashing rights under United States Copyright Law: harmonizing an employer's economic right with the artist-employee's moral rights in a work made for hire", Harvard Cyber Law, Cambridge, , available (December 2001) at: cyber.law.harvard.edu/ metaschool/Fisher/integrity/Links/Articles/fielkow.html

Rosenblatt, B. (March, 1998), "Moral rights basics", Harvard University, Cambridge, MA, available (December 2001) at: cyber.law.harvard.edu/property/library/ moralprimer.html

Schulze, G. (1998), Meine Rechte als Urheber: Urheber und Verlagsrecht, 3, Ausgabe, C.H. Beck, Munich.

Standler, R.B. (1998), "Moral rights of authors in the USA", available (December 2001) at: www.rbs2.com/moral. htm

UK Patent Office (nd), "Intellectual property: what are moral rights?", available (December 2001) at: www. intellectual-property.gov.uk/std/faq/copyright/ moral_rights.htm 